\title{
Pembangunan Pariwisata Kulon Progo Melalui Konsep Green Economy dan Blue Economy
}

\section{Harits Dwi Wiratma, Tanti Nurgiyanti}

\author{
Program Studi Ilmu Hubungan Internasional, Universitas Respati Yogyakarta - Indonesia \\ Email: wiratmaharits1985@gmail.com \\ Submitted: 03 November 2019 | Accepted: 30 Desember 2019
}

\begin{abstract}
The development of the tourism sector is carried out massively, because this sector is one of the biggest foreign exchange earners after oil palm in Indonesia. Each local government competes one another to improve in the competitiveness of its tourism sector, like Kulon Progo district. The massive development in this sector is feared to have environmental impacts. Environmental support in tourism development also needs concern. Green Economy and Blue Economy concept is expected to provide solutions both in terms of tourism industry or sustainable development for the tourism sector, because the environment becomes part of tourism development.
\end{abstract}

Keywords: Sustainable, Tourism, Development, Blue Economy, Green Economy, Society, Empowerment.

\begin{abstract}
Abstrak
Pembangunan sektor pariwisata sangat masif dilakukan, karena sektor ini merupakan salah satu penyumbang devisa terbesar setelah sawit. Pemerintah daerah berlomba-lomba untuk meningkatkan daya saing sektor pariwisatanya, salah satunya adalah pemerintah Kabupaten Kulon Progo. Pembangunan yang massif dalam sektor ini dikhawatirkan memiliki dampak lingkungan. Daya dukung lingkungan terhadap pembangunan pariwisata juga harus diperhatikan. Melalui Konsep Green Economy dan Blue Economy diharapkan memberikan solusi baik dari segi industri pariwisata ataupun pembangunan keberlanjutan bagi sektor pariwisata, karena lingkungan menjadi bagian dalam pembangunan pariwisata.
\end{abstract}

Kata Kunci: Pembangunan, Pariwisata, Berkelanjutan, Blue Economy, Green Economy, Pemberdayaan, Masyarakat.

\section{PENDAHULUAN}

Indonesia merupakan salah satu negara yang memiliki potensi sumber daya alam dan sumber daya manusia. Hal tersebut menjadi modal utama untuk menggerakkan roda pembangunan bangsa. Dalam era global saat ini pembangunan menjadi hal yang penting untuk pengembangan suatu negara. Oleh karena itu, pemerintah selaku pemangku kepentingan memiliki peran dalam mengeksplorasi potensi atau sumber kekuatan bagi meningkatnya perekonomian suatu daerah. Negara tidak dapat berkembang secara signifikan apabila daerah-daerah di Indonesia tidak memiliki kekuatan lokal yang ada. Salah satunya kekuatan lokal atau kemampuan daerah dapat dilihat dari industri pariwisatanya. 
Industri pariwisata menjadi salah satu penyumbang devisa kedua setelah kelapa sawit. Artinya, pembangunan pariwisata tidak terpusat di Pulau Bali. Akan tetapi pembangunan industri pariwisata dapat memberikan dampak positif bagi daerah untuk dijadikan tujuan wisata di masa yang akan datang. Pembangunan industri pariwisata notabene di Indonesia tidak hanya terpusat di Pulau Bali, disisi lain pemerintah perlu membuka peluang bagi daerah lain untuk mengembangkan potensinya.

Adanya Otonomi Daerah memberikan pengaruh yang sangat signifikan terhadap pendapatan daerah apabila Gubernur, Bupati atau pemangku kebijakan memiliki visi dan misi dalam pengembangan daerah. Ada beberapa pokok kajian dari pemerintah terkait prioritas pembangunan nasional dari Presiden Jokowi. Sektor prioritas pembangunan 2017 antara lain Pangan, Energi, Maritim, Pariwisata, Kawasan Industri dan KEK. Persaingan global memberikan peluang bagi siapapun atau daerah mana pun untuk bersaing tidak hanya level nasional tetapi bersaing di tingkat internasional atau global. Pendekatan dalam kerja sama antar pemerintah melalui sister city dapat digalakkan secara massif. Bagi pasar wisatawan, setiap daerah tujuan wisata memiliki sejumlah keunggulan atau daya saing yang dijadikan sebagai basis penentuan untuk memilih atau menjadikannya sebagai target destinasi (Janianton, 2013).

Dalam keterkaitan dengan riset yang mengangkat pemberdayaan masyarakat dan aspek lingkungan berkelanjutan melalui konsep green economy dan blue economy peneliti akan melakukan kajian di Daerah Kebupaten Kulon Progo. Daerah Kulon Progo merupakan daerah dalam lima tahun terakhir mengalami pertumbuhan yang signifikan. Hal ini dapat kita analisa ke depan adanya pembangunan lintas sektor menjadi kekuatan Kulon Progo untuk menjadi tempat yang prospek untuk investasi. Pembangunan Pelabuhan Tanjung Adikarto, Bandara Internasional, Wisata Alam serta peningkatan ekonomi kreatif yang digalakkan oleh pemerintah. Semakin dikelola secara baik dan professional dalam hal infrastruktur maka akan membantu perekonomian daerah. Faktor infrastruktur menjadi salah satu penentu pembangunan di segala bidang. Pengembangan pemberdayaan masyarakat dan aspek lingkungan berkelanjutan melalui konsep green economy dan blue economy memerlukan infrastruktur yang memadai. Di sisi lain, aspek-aspek yang lain perlu diperhatikan dalam meningkatkan produktifitas pemberdayaan tersebut. Di lain pihak faktor lingkungan menjadi sangat penting guna 
mendukung konsep pemberdayaan khususnya menyangkut aspek pembangunan pariwisata. Kebersihan dan kelestarian menjadi daya tarik tersendiri dalam meningkatkan jumlah kunjungan pariwisata lokal maupun mancanegara. Hal tersebut dapat kita lihat keberhasilan pembangunan pariwisata internasional suatu negara. Keberhasilan tersebut memiliki 14 parameter dalam TTCI (Travel \& Touris Competitiveness Index) yang dikeluarkan oleh World Economic Forum seperti tabel dibawah ini:

\section{Gambar 1 Indeks Keunggulan Pariwisata Dunia}

\begin{tabular}{l} 
SUBINDEX A: \\
T\&T regulatory framework \\
- Policy rules and regulations \\
- Environmental \\
sustainability \\
- Safety and security \\
- Health and hygiene \\
- Prioritization of Travel \& \\
Tourism \\
\hline
\end{tabular}

SUBINDEX B:
T\&T business environment
and infrastructure
-Air transport infrastructure
- Ground transport
infrastructure
-Tourism infrastructure
- ICT infrastructure
-Price competitiveness in the
T\&T industry

\begin{tabular}{l} 
SUBINDEX C: \\
T\&T human, cultural, and \\
natural resources \\
\hline - Human resources \\
-Affinity for Travel \& \\
- Nourism \\
- Natural resources \\
- Cultural resources
\end{tabular}

Sumber: The Travel \& Tourism Competitiveness Report 2009 World Economic Forum

Dalam perkembangannya industri pariwisata merupakan sebuah industri jasa yang telah diatur dalam GATS. Hal ini sudah menjadi pembahasan di tingkat WTO (World Trade Organization) bahwa perdagangan jasa diatur dalam General Agreement on Trade in Services (GATS). Di mana Indonesia memiliki komitmen dalam bidang jasa pariwisata yang diimplementasikan dalam perjanjian pembentukan WTO yang terdapat di Schedule of Specific Commitments.

Pembangunan Pariwisata sedang marak digalakkan baik oleh pemerintah pusat maupun pemerintah daerah. Hal ini dilakukan karena sektor pariwisata merupakan salah satu bidang yang potensial bagi pendapatan Negara. Pembangunan pariwisata yang semakin massif diharapkan juga memperhatikan daya dukung lingkungannya. Aspek lingkungan dalam pembangunan merupakan salah satu tujuan pembangunan berkelanjutan.

Dalam perdagangan internasional dikenal teori keunggulan absolut dan keunggulan komparatif. Industri pariwisata merupakan perdagangan jenis jasa. Melalui teori tersebut maka setiap daerah akan mencari dan mengeksplorasi keunggulan pariwisata daerah agar memiliki daya saing. Namun hal tersebut dapat memicu eksploitasi terhadap lingkungan di 
mana pembangunan pariwisata tersebut dilakukan. Oleh karena itu pembangunan pariwisata juga harus mengedepankan aspek lingkungan agar memiliki manfaat ekonomi dan keberlanjutannya dapat dinikmati bagi setiap orang. Tujuan Pembangunan berkelanjutan adalah memberi keadilan bagi generasi sekarang maupun generasi penerus yang akan datang tanpa mengurangi hak generasi tersebut. Dalam sejarah pembangunan di banyak negara, sektor kepariwisataan telah terbukti berperan penting dalam menyumbang perkembangan perekonomiannya, khususnya dalam dua dekade terakhir, yang ditunjukkan dengan meningkatnya tingkat kesejahteraan ekonomi bangsa-bangsa yang menjadikan kepariwisataan sebagai industri hilirnya untuk mengungkit pertumbuhan dari kegiatan-kegiatan usaha dan penyerapan tenaga kerja dari sektor-sektor usaha/kegiatan yang ada didepan dan di belakangnya (Sunaryo, 2013).

\section{KERANGKA TEORITIK}

Pengertian ekonomi hijau dari United Nations Environment Programme (UNEP) dalam kalimat sederhana dapat diartikan sebagai perekonomian yang rendah karbon (tidak menghasilkan emisi dan polusi lingkungan), hemat sumber daya alam dan berkeadilan sosial. Konsep ini memberikan pesan kepada seluruh aktor yang berkepentingan untuk mematuhi prinsip-prinsip pembangunan berkelanjutan. Indonesia merupakan salah negara yang memiliki potensi dalam hal pengembangan dan pembangunan negara yang berwawasan lingkungan.

Konsep ekonomi hijau menjadi sangat signifikan diterapkan di Indonesia mengingat ancaman bencana semakin nyata. Bencana alam menjadi unsur yang perlu diantisipasi oleh seluruh elemen masyarakat baik pemangku kebijakan ataupun masyarakat pada umumnya, perlu ada pendekatan secara politik, ekonomi, sosial maupun budaya. Hal ini tidak bisa berhasil tanpa adanya sinergi yang sifatnya koordinasi berlandaskan kesadaran untuk menyelamatkan lingkungan. Sehingga tujuan pembangunan ekonomi nasional yang berwawasan lingkungan dapat tercapai. Kabupaten Kulonprogo merupakan salah satu wilayah yang memiliki potensi alam yang lengkap dengan memiliki destinasi wisata alam dan bahari. Kondisi tersebut dapat dijadikan sebagai salah satu promosi wisata dari Kulonprogo.

Sedangkan konsep blue economy pertama kali dilontarkan oleh Prof. Gunter Pauli dalam bukuya yang berjudul The Blue Economy, 10 Years, 100 Innovations, 100 Million Jobs, yang menggambarkan potensi manfaat 
teorinya bagi perlindungan lingkungan hidup komunitas dunia, pelestarian sumber daya alam, inisiatif pengurangan biaya industri dengan pengalihan pada konsumsi energi hijau, bersih, hasil daur ulang atau terbarukan. Dalam bukunya tersebut, Pauli (2006) menyebutkan baahwa Blue Economy is a collection of innovations contributing towards the creation of a global consciousness rooted in the search for practical solutions based on sustainable natural systes. Istilah blue economy merupakan sebuah paradigma (konsep) baru yang bertujuan untuk menghasilkan pertumbuhan ekonomi dari sektor kelautan dan perikanan, sekaligus menjamin kelestarian sumberdaya serta lingkungan pesisir dan lautan (Menteri Kelautan dan Perikanan Syarif C. Sutardjo, 2012).

Blue economy merupakan model pendekatan pembangunan ekonomi yang tidak lagi mengandalkan pembangunan ekonomi berbasis eksploitasi sumber daya alam dan lingkungan yang berlebihan. Hal tersebut, merupakan suatu lompatan besar dalam pembangunan dengan meninggalkan praktek ekonomi yang mementingkan keuntungan jangka pendek serta menggerakkan perekonomian yang rendah karbon (low carbon economy).

Model pedekatan blue economy diharapkan mampu menjawab ketergantungan antara ekonomi dan ekosistem serta dampak negatif akibat aktivitas ekonomi termasuk perubahan iklim dari pasar global. Blue economy sebagai konsep baru pembangunan kelautan dan perikanan akan diarahkan pada pembangunan ekonomi yang seimbang antara pemanfaatan sumber daya kelautan dan perikanan dengan upaya pengelolaan lingkungan secara optimal dan berkelanjutan.

Di saat ekonomi eksploitatif hanya bertujuan untuk mencapai profit saja. Konsep BGE justru hadir sebagai konsep ekonomi yang ideal dan berkelanjutan berbasis manivestasi alam yang lebih baik, baik daratan (green) maupun lautan (blue). Konsep BGE juga didasari atas tiga pilar utama yakni profit, people, dan planet. Jadi dengan BGE, profit akan tetap tercapai baik itu keuntungan secara finansial maupun terciptanya energi baru sebagai tujuan utama, namun tetap mementingkan alam sehingga tidak menambah kerusakan lingkungan justru menyelasaikannya. Jadi tidak mengherankan jika BGE mendatangkan banyak manfaat besar bagi manusia (people) dan lingkungan (planet).

Permasalahan lingkungan menjadi salah satu isu yang sangat strategis dalam tataran hubungan internasional. Kondisi tersebut memiliki dampak yang tidak seimbang di masyarakat, karena dapat menimbulkan permasalahan sosial 
maupun non sosial. Jika keamanan internasional dan ekonomi global adalah dua isu area utama tradisional dalam politik dunia, sebagian penstudi sekarang menyatakan bahwa lingkungan hidup telah muncul sebagai issue area yang ketiga (Porter dan Brown, 1996). Oleh karena itu, lingkungan dapat menjadi sumber kemajuan suatu bangsa dengan cara mengembangkan dan mengeksplorasi secara baik. Hal ini memberikan pengaruh bagi pemerintah atau pelaku yang memiliki konsen terhadap lingkungan. Di sisi lain, era globalisasi menjadi sebuah pertarungan di berbagai sektor pembangunan. Globalisasi dapat memberikan dampak positif atau negatif terhadap kelangsungan manusia. Meskipun pembangunan diseluruh bidang tetap berjalan. Pernyataan Kaum Modernis "lingkungan hidup bukan masalah serius". Kemajuan dalam pengetahuan dan teknologi akan memungkinkan kita melindungi lingkungan hidup" (Jackson dan Sorensen, 2005).

\section{HASIL DAN PEMBAHASAN}

Kabupaten Kulon Progo merupakan salah satu kabupaten dari lima kabupaten/kota di Propinsi Daerah Istimewa Yogyakarta yang terletak di bagian barat. Luas wilayah Kabupaten Kulon Progo adalah 58.627,54 hektar, secara administratif terbagi menjadi 12 kecamatan yang meliputi 88 desa dan 930 dusun. Penggunaan tanah di Kabupaten Kulon Progo, meliputi sawah 10.732,04 Ha (18,30\%); tegalan $7.145,42 \mathrm{Ha}(12,19 \%) ;$ kebun campur $31.131,81 \quad \mathrm{Ha} \quad(53,20 \%)$; perkampungan seluas $3.337,73 \mathrm{Ha}$ (5,69\%); hutan $1.025 \mathrm{Ha}(1,75 \%)$; perkebunan rakyat $486 \mathrm{Ha}(0,80 \%)$; tanah tandus $1.225 \mathrm{Ha}(2,09 \%)$; waduk $197 \mathrm{Ha}(0,34 \%)$; tambak $50 \mathrm{Ha}$ $(0,09 \%)$; dan tanah lain-lain seluas $3.315 \mathrm{Ha}$ (5,65\%) (Profil Kabupaten Kulonprogo).

Kabupaten Kulon Progo dilewati oleh 2 (dua) prasarana perhubungan yang merupakan perlintasan nasional di Pulau Jawa, yaitu jalan nasional sepanjang 28,57 km dan jalur Kereta Api sepanjang kurang lebih $25 \mathrm{~km}$. Hampir sebagian besar wilayah di Kabupaten Kulon Progo dapat dijangkau dengan menggunakan transportasi darat. Situasi ini menjadi salah satu peluang untuk menarik wisatawan. Potensi Kabupaten Kulonprogo menjadi destinasi wisata menunjukkan tren yang meningkat. Keberadaan Bandara baru Yogyakarta International Airport, Pelabuhan Tanjung Adikarto, serta destinasi wisata kekinian (instagramable) menarik untuk diteliti lebih lanjut. Pada penyelenggaraan Anugrah Pesona Indonesia (API) 2018 kabupaten ini memperoleh 2 penghargaan sekaligus, yaitu Tari Angguk dalam kategori 
atraksi budaya terpopuler dan Nglinggo dalam kategori Eko Wisata Terpopuler.

Dalam kegiatan pariwisata merupakan kegiatan yang berbasis komunitas, yaitu bahwa sumber daya dan keunikan komunitas lokal baik berupa elemen fisik mapun non fisik (tradisi dan budaya) yang melekat pada komunitas tersebut merupakan unsur penggerak utama kegiatan pariwisata itu sendiri, di lain pihak komunitas lokal yang tumbuh dan hidup berdampingan dengan suatu objek wisata tidak dapat dipungkiri sebenarnya telah menjadi bagian dari sistem ekologi yang saling berkaitan (Murphy dikutip Purnamasari 2011, 49-64). Dalam pengembangan kepariwisataan, aspek pemberdayaan komunitas lokal telah menjadi salah satu kesepakatan dan komitmen yang harus diwujudkan untuk mendukung pengembangan pariwisata secara berkelanjutan, yang menekankan terwujudnya kualitas sumber daya lingkungan (quality of resources), kualitas pengalaman wisata (quality of visitor satisfaction), serta kualitas kehidupan masyarakat lokal (quality of local community) (Murphy dikutip Purnamasari 2011, 49-64).

Terdapat beberapa komponen pengembangan pariwisata yang berkaitan dengan pendekatan perencanaan pariwisata, yaitu: atraksi wisata yang mencakup wisata alam, budaya, dan atraksi lainnya; akomodasi berupa hotel dan jenis fasilitas lainnya yang berhubungan dengan pelayanan terhadap wisatawan yang menginap; fasilitas dan pelayanan wisata lainnya yang berhubungan dengan kegiatan pariwisata; fasilitas dan layanan tranportasi yang mencakup transportasi darat, laut, dan udara; infrastruktur lainnya seperti penyediaan air bersih, tenaga listrik, telekomunikasi, dan lain-lain; elemen institusi yang terkait dengan pengembangan pariwisata, elemen ini penting untuk mengatur dan merencanakan program-program yang dapat meningkatkan aktivitas pariwisata (Inskeep dikutip I Made Adikampana 2016, Modul Mata Kuliah Pariwisata Berbasis Masyarakat Integrasi Masyarakat Lokal Dalam Perencanaan Destinasi Pariwisata).

Masyarakat dapat berpartisipasi dan memiliki fungsi dalam perencanaan. Pertama, memberikan sumbangan berupa dukungan terhadap pelaku perencana dan aktivitasnya. Kedua, adalah sumbangan dalam hal kebijaksanaan dan pengetahuan dalam rencana pembangunan, serta dalam mengidentifikasikan dari pelaku perencanaan. Ketiga, adalah merupakan fungsi yang paling penting, yaitu sebagai pengawas dalam hak- hak mereka sendiri dan hak orang lain dalam merancang dan penyerahan 
kebijaksanaan (Tampubolon, 1977). Salah satu prinsip kepariwisataan yang terkandung dalam Undang-undang No.10 Tahun 2009 tentang kepariwisataan adalah memberdayakan masyarakat setempat di mana masyarakat berhak berperan dalam proses pembangunan kepariwisataan dan berkewajiban menjaga dan melestarikan daya tarik wisata; serta membantu terciptanya suasana aman, tertib, bersih, berperilaku santun, dan menjaga kelestarian lingkungan destinasi pariwisata. Selain itu para pengusaha di bidang pariwisata juga berkewajiban

mengutamakan penggunaan produk masyarakat setempat, produk dalam negeri, dan memberikan kesempatan kepada tenaga kerja lokal dan berperan aktif dalam upaya pengembangan prasarana dan program pengembangan masyarakat. Masyarakat memiliki kesempatan yang sama dan seluasluasnya untuk berperan serta dalam penyelenggaraan kepariwisataan, termasuk penyampaian saran, pendapat dan pertimbangan untuk pengambilan keputusan dalam rangka proses perencanaan, pelaksanaan dan pengawasan penyelenggaraan kepariwisataan. Pemberdayaan merupakan strategi yang sangat potensial dalam meningkatkan ekonomi, sosial dan transformasi budaya.
Pariwisata berbasis masyarakat merupakan akivitas ekonomi penting yang jika dikembangkan dengan tepat dapat mengatasi sejumlah tantangan pembangunan, termasuk pengurangan kemiskinan, pengembangan ekonomi lokal, perdamaian dan keselarasan masyarakat, dan manajemen sumber daya alam dan lingkungan yang berkesinambungan (Damanik, et al, 2006).

Dalam buku Tourism and Development in the Third World, terdapat 3 (tiga) tipe pekerjaan yang tercipta dari kegiatan pariwisata, yaitu pekerjaan langsung dari adanya pengeluaran untuk fasilitas wisata, misalnya jasa perhotelan, pekerjaan tidak langsung pada bisnis yang dipengaruhi oleh kegiatan pariwisata sekunder, misalnya transportasi lokal, kerajinan dan perbankan, dan yang terakhir adalah pekerjaan yang muncul akibat adanya pengeluaran yang dilakukan oleh penduduk lokal dari pendapatan wisatawannya (Lea dikutip Andi Maya Purnamasari, 1995, 49 64).

Beberapa prinsip dalam penerapan pariwisata berbasis masyarakat adalah sebagai berikut: small scale, tahapan dimulai dari lapis paling bawah, menekankan pada pemenuhan basic needs dan self reliance; proses pengambilan keputusan dilakukan oleh masyarakat dan otoritas tertinggi ada di tangan masyarakat 
lokal; memegang prinsip-prinsip kesamaan sekaligus perbedaan dan ketimpangan; optimalisasi pemanfaatan sumber daya lokal; tidak mengabaikan identitas masyarakat lokal; menekankan pada buman capital bukan financial capital; dan menekankan pada manfaat dan distribusi produksi bukan akumulasi modal/capital (Drake dikutip Purnamasari, 2011, 4964).

Berdasarkan hasil wawancara yang diperoleh peneliti dari Bappeda, Bapak Fajar Pramukti bagian Subbid Penanaman Modal, Tenaga Kerja dan Pariwisata Kabupaten Kulon Progo menjelaskan bahwa seluruh kegiatan di dalam bidang pariwisata dilakukan selalu memperhatikan aspek lingkungan berkelanjutan. Hal ini sesuai dengan Prinsip Sustainable Tourism, Sapta Pesona maupun Green Tourism. Adapun kegiatan yang mendukung tersebut menurut Ardi, selaku bagian Kapasitas dan Ekonomi Kreatif Dinas Pariwisata Kabupaten Kulon Progo diantaranya himbauan kepada pengelola maupun pengunjung destinasi wisata untuk mengurangi penggunaan sampah plastik, ketersediaan tempat sampah yang terpilah, serta kegiatan memungut sampah menuju obyek wisata seperti yang dilakukan di Perkebunan Teh Nglinggo.

Pada aspek pemberdayaan masyarakat terdapat destinasi yang dikelola oleh pemerintah dan masyarakat. Tercatat 24 Pokdarwis yang berada di Kabupaten Kulonprogo. Saat ini terdapat 30 Homestay dan 11 desa wisata. Pemerintah Kabupaten Kulonprogo mendorong terciptanya destinasi wisata baru mengigat keberadaan suatu obyek wisata dapat meningkatkan kesejahteraan masyarakat sekitar. Namun aspek pengelolaan pariwisata berkelanjutan dan berbasis lingkungan selalu ditekankan. Pariwisata memiliki basis alam, apabila terjadi kerusakan maka selesai sudah. Oleh karena itu pihak pemerintah selalu memfasilitasi dan membina apabila terdapat keinginan masyarakat membuat obyek wisata. Pemerintah Kabupaten Kulonprogo juga meningkatkan kapasitas para pemandu wisata. Saat ini pemerintah telah memberikan pelatihan 15 pemandu wisata oleh Dewan Pimpinan Daerah (DPD) Himpunan Pramuwisata Indonesia (HPI) DIY dan BNSP (Badan Nasional Sertifikasi Profesi) serta Lembaga Sertifikasi Profesi Pramuwisata Indonesia (LSP Pramindo). Diharapkan para pemandu wisata ini dapat memberikan pelayanan yang optimal perhadap para pengunjung obyek wisata di Kulonprogo. Kegiatan peningkatan kapasitas pemandu wisata ini bahkan akan terus dilakukan. Selain melalui DPD HPI, Balai Latihan Kerja (BLK) 
Kulonprogo juga melakukan kegiatan pelatihan ini.

Dalam aspek pendukung pariwisata terdapat home stay yang dikelola oleh warga masyarakat sekitar obyek wisata. Saat ini home stay pun mendapat perhatian khusus agar sesuai dengan standar ASEAN. Pembangunan pariwisata memiliki keterkaitan dengan berbagai aspek diantaranya pemerintah, pelaku, masyarakat, fasilitas, lingkungan, ekonomi, sosial bahkan politik. Namun tujuan dari pembangunan pariwisata yang utama adalah meningkatkan tingkat kunjungan baik dari wisatawan domestik maupun wisatawan asing.

Pembangunan didesain sesuai dengan bagaimana ekosistem bekerja, karena diakui bahwa alam bekerja secara efisien. Prinsip efisiensi sumber daya alam tersebut dianut dalam blue economy. Pertama, nir-limbah (zero waste) dan menekankan sistem siklikal dalam proses produksi, sehingga tercipta produksi bersih. Artinya limbah dari sebuah proses produksi akan menjadi bahan baku atau sumber energi bagi produksi berikutnya. Kedua, inklusi sosial (social inclusiveness), yang berarti pemerataan sosial dan kesempatan kerja yang banyak untuk orang miskin. Ketiga, inovasi dan adaptasi, yang memperhatikan prinsip hukum fisika dan sifat alami yang adaptif. Keempat, efek ekonomi pengganda, yang berarti aktivitas ekonomi yang dilakukan akan memiliki dampak yang luas dan tidak rentan terhadap gejolak harga pasar. Hal ini karena Blue Economy menekankan produk ganda sehingga tidak bergantung pada satu produk (core business) (Satria, 2015).

Dinas Perikanan dan Kelautan, Sudarmanto Kabid Pengembangan Usaha mengatakan bahwa belum pernah mendengar konsep Blue Economy. Namun pemerintah Kulonprogo dalam aspek pemberdayaan masyarakat, telah memberikan bantuan dan pelatihan bagi masyarakat khususnya nelayan dalam pengolahan hasil perikanan. Kelompok nelayan diberikan pelatihan berupa mengolah ikan crispy dan frozen food. Meskipun pada akhirnya produksi pengolahan ikan ini terkendala alat serta pemasaran, karena harga makanan olahan ini mahal sehingga tidak terjangkau oleh masyarakat. Selain itu di Kabupaten Kulonprogo terdapat Kelompok Budidaya Ikan (Pokdakan) yang telah melakukan mina padi yang merupakan combined and integrated farming antara budidaya ikan dan budidaya padi di sawah. Melalui mina padi, produktifitas sawah diyakini akan meningkatkan produksi ikan secara organik dan ramah lingkungan, baik dari padi yang dihasilkan maupun hasil panen dari ikan. Sistem mina padi juga dipercaya akan mencegah dan menahan laju alih 
fungsi lahan pangan menjadi lahan non-pangan. Mina padi juga diharapkan menjadi kegiatan yang dapat menyerap tenaga kerja bersifat padat karya sehingga mampu mencegah urbanisasi.

Masalah kerusakan alam merupakan politicized environment. Artinya persoalan lingkungan tidak dapat dipahami secara terpisah dari konteks politik dan ekonomi dimana masalah itu muncul. Jadi kerusakan alam, bukanlah masalah teknis semata yang hanya bisa diselesaikan secara teknologi, melainkan merupakan problem tata kelola yang harus diselesaikan secara ekonomi-politik (Bryant dan Bailey dikutip Satria, 2015, 8).

\section{KESIMPULAN}

Pembangunan didesain sesuai dengan bagaimana ekosistem bekerja, karena diakui bahwa alam bekerja secara efisien. Prinsip efisiensi sumber daya alam tersebut dianut dalam blue economy. Pertama, nir-limbah (zero waste) dan menekankan sistem siklikal dalam proses produksi, sehingga tercipta produksi bersih. Artinya limbah dari sebuah proses produksi akan menjadi bahan baku atau sumber energi bagi produksi berikutnya. Kedua, inklusi sosial (social inclusiveness), yang berarti pemerataan sosial dan kesempatan kerja yang banyak untuk orang miskin. Ketiga, inovasi dan adaptasi, yang memperhatikan prinsip hukum fisika dan sifat alami yang adaptif. Keempat, efek ekonomi pengganda, yang berartiaktivitas ekonomi yang dilakukan akan memiliki dampak yang luas dan tidak rentan terhadap gejolak harga pasar. Hal ini karena Blue Economy menekankan produk ganda sehingga tidak bergantung pada satu produk (core business) (Satria, 2015).

Dinas Perikanan dan Kelautan, Sudarmanto Kabid Pengembangan Usaha mengatakan bahwa belum pernah mendengar konsep Blue Economy. Namun pemerintah Kulonprogo dalam aspek pemberdayaan masyarakat, telah memberikan bantuan dan pelatihan bagi masyarakat khususnya nelayan dalam pengolahan hasil perikanan. Kelompok nelayan diberikan pelatihan berupa mengolah ikan crispy dan frozen food. Meskipun pada akhirnya produksi pengolahan ikan ini terkendala alat serta pemasaran, karena harga makanan olahan ini mahal sehingga tidak terjangkau oleh masyarakat. Selain itu di Kabupaten Kulonprogo terdapat Kelompok Budidaya Ikan (Pokdakan) yang telah melakukan mina padi yang merupakan combined and integrated farming antara budidaya ikan dan budidaya padi di sawah. Melalui mina padi, produktifitas sawah diyakini akan meningkatkan produksi ikan secara organik dan ramah lingkungan, baik dari padi yang 
dihasilkan maupun hasil panen dari ikan. Sistem mina padi juga dipercaya akan mencegah dan menahan laju alih fungsi lahan pangan menjadi lahan non-pangan. Mina padi juga diharapkan menjadi kegiatan yang dapat menyerap tenaga kerja bersifat padat karya sehingga mampu mencegah urbanisasi.

Masalah kerusakan alam merupakan politicized environment. Artinya persoalan lingkungan tidak dapat dipahami secara terpisah dari konteks politik dan ekonomi dimana masalah itu muncul. Jadi kerusakan alam, bukanlah masalah teknis semata yang hanya bisa diselesaikan secara teknologi, melainkan merupakan problem tata kelola yang harus diselesaikan secara ekonomi-politik (Bryant dan Bailey dikutip Satria, 2015, p. 8).

\section{REFERENSI}

Bambang, Sunaryo. (2013) Kebijakan Pembangunan Destinasi Pariwisata Konsep dan Aplikasi di Indonesia. Yogyakarta: Gava Media.

BPKP Kulonprogo. (2019) Profil Kulon Progo (Online). Tersedia di: http://www.bpkp.go.id/diy/konten/83 4/Profil-Kabupaten-Kulonprogo

(Diakses: 23 Juni 2019).

Damanik Janianton. (2013) Pariwisata Indonesia Antara Peluang dan Tantangan.Yagyakarta: Pustaka Pelajar.

Jackson, R dan Sorensen,G. (2005) Pengantar Studi Hubungan Internasional. Yogyakarta: Pustaka Pelajar.
Porter,G dan Brown, J.W. (1996) Global Environment Politics. Boulder: Westview Press.

Purnamasari, A.M. (2011) "Pengembangan Masyarakat untuk Pariwisata di Kampung Wisata Toddabojo Provinsi Sulawesi Selatan", Jurnal Perencanaan Wilayah dan Kota, Vol. 22 No. 1, hlm.49 -64 .

Rani, Faisyal \& Cahyasari, Wulandari. (2015) "Motivasi Indonesia Dalam Menerapkan Model Kebijakan Blue Economy Masa Pemerintahan Joko Widodo", Jurnal Transnasional, Vol. 7, No. 1.

Tourism Planning; An Integrated and Sustainable Development Approach, Van Nostrand Reinhold=Modul Mata Kuliah Pariwisata Berbasis Masyarakat Integrasi Masyarakat Lokal Dalam Perencanaan Destinasi Pariwisata, I Made Adikampana, Program Studi S1 Destinasi Pariwisata FAKULTAS PARIWISATA Universitas Udayana 2016.

Undang-undang No.17 tahun 2007. 